\title{
PENERAPAN FORWARD CHAINING DALAM MENINGKATKAN KEMAMPUAN MANDI SECARA MANDIRI PADA REMAJA DENGAN MILD INTELLECTUAL DISABILITY
}

\author{
Adisa Mustikawati ${ }^{1}$, Woro Kurnianingrum ${ }^{2}$ \\ ${ }^{1}$ Fakultas Psikologi Universitas Tarumanagara \\ adisa.mustikawati@gmail.com \\ ${ }^{2}$ Fakultas Psikologi Universitas Tarumanagara \\ woro_kurnianingrum@yahoo.com
}

\begin{abstract}
ABSTRAK
Hambatan dalam fungsi adaptif merupakan salah satu karakteristik individu dengan intellectual disability. Hal yang termasuk ke dalam fungsi adaptif, yaitu kemampuan bina diri atau perawatan diri. Individu dengan mild intellectual disability merupakan individu yang mampu didik, yaitu mampu untuk mempelajari keterampilan hidup sehari-hari. Salah satu kemampuan adaptif yang dapat ditingkatkan pada individu dengan mild intellectual disability adalah mandi secara mandiri. Kemampuan mandi secara mandiri merupakan salah satu kemampuan yang perlu dikuasai karena berkaitan dengan kebersihan diri sendiri dan kesehatan kulit. Dengan menggunakan teknik forward chaining, satu orang remaja dengan mild intellectual disability mendapatkan pelatihan untuk meningkatkan kemampuannya dalam mandi secara mandiri, terutama dalam mempertahankan kemampuan yang sudah dikuasai dan melatih kemampuan yang sebelumnya belum ada atau ditunjukkan. Pemberian prompting dan social reinforcers juga digunakan dalam penelitian ini. Prompt yang diberikan meliputi instruksi atau arahan. Intervensi dilakukan selama 9 sesi. Hasil dari penelitian ini adalah telah terbentuk perilaku mandi sebagai bagian dari kemampuan bina diri pada remaja dengan mild intellectual disability. Peneliti menyimpulkan bahwa program modifikasi perilaku dengan menggunakan teknik forward chaining disertai dengan pemberian prompt dan social reinforcers menampilkan efektivitas jangka panjang, di mana perilaku mandi secara mandiri dengan langkah-langkah yang tepat dapat dipertahankan oleh subyek apabila terus dilakukan penguatan dengan berulang dan jangka waktu yang panjang atau sesi lebih banyak.
\end{abstract}

Kata Kunci: intellectual disability, remaja, forward chaining, social reinforcers, mandi.

\section{PENDAHULUAN}

\section{Latar Belakang}

Intellectual disability bukan merupakan suatu gangguan mental ataupun gangguan medis, melainkan sebuah istilah untuk menjelaskan suatu gangguan yang ditandai dengan keterbatasan yang signifikan pada fungsi intelektual dan fungsi adaptif yang dimulai sebelum usia 18 tahun. Keterbatasan fungsi intelektual secara umum seperti penalaran, pemecahan masalah, perencanaan, berpikir abstrak, penilaian, pembelajaran akademis, dan belajar dari pengalaman. Sedangkan keterbatasan fungsi adaptif meliputi area konseptual, sosial, dan praktis baik di rumah maupun di lingkungan masyarakat (APA, 2013; Mash \& Wolfe, 2013). Diagnostic and Statistical Manual of Mental Disorder V (DSM 5) membagi gangguan intellectual disability berdasarkan dengan tingkat keparahan dalam fungsi kemampuan adaptif yang berada pada rentang tingkatan mild hingga profound (Nelson \& Israel, 2015).

Menurut American Association on Mental Deficiency (AAMD) Adaptive Behavior Scale (1983) fungsi adaptif berpedoman pada kualitas kinerja sehari-hari dalam menghadapi tuntutan lingkungan. Kualitas adaptasi umum dimediasi oleh tingkat kecerdasan. Berdasarkan hal tersebut, kedua konsep dari adaptif menjadi tumpang tindih dalam pemaknaannya. Meski demikian, dari pertimbangan 
definisi fungsi adaptif, dengan menghadapi stress sehari-hari, fungsi adaptif mengarah kepada apa yang orang lakukan untuk mengurus diri sendiri dan berhubungan dengan orang lain dalam kehidupan sehari-hari daripada potensi abstrak yang diungkapkan dalam kemampuan intelegensi.

Fungsi adapatif berlandaskan pada keefektifan individu dalam menyelesaikan permasalahan seharihari, kemampuan individu untuk hidup mandiri, dan kemampuan untuk mengikuti standar lingkungan. Hambatan yang terdapat pada anak dengan intellectual disability tampak pada perkembangan kemampuan dasar seperti motorik, kemampuan berbahasa yang menjadi isyarat untuk berkomunikasi dengan orang lain, penyesuaian emosional diri yang kurang, sulit untuk bersosialisasi dengan orang lain, kemampuan bantu diri atau kemandirian seperti berpakaian, makan, kemampuan atau cara buang air, kebersihan diri, dan sebagainya (Sattler, 2002).

The American Association of Mental Deficiency Adaptive Behavior Scales (AAMD - ABS) membagi fungsi adaptif, yang mengacu kepada kemampuan bina diri (fungsi berdikari) menjadi beberapa bagian, yaitu mengenai cara makan, cara buang air, kebersihan, penampilan, memelihara pakaian, berpakaian dan melepaskan pakaian, berpergian, dan fungsi berdikari lainnya. Anak dengan intellectual disability biasanya akan mengalami beberapa hambatan dalam area bina diri tersebut. Kemampuan bina diri, seperti makan, berpakaian, dan menjaga kebersihan tubuh memberikan kontribuasi terhadap kesehatan, kemandirian, self determined, penerimaan sosial, dan kualitas hidup seseorang (Ersoy, Tekin-Iftar, \& Kircaali-Iftar, 2009).

Individu dengan intellectual disability dapat disebut juga sebagai individu dengan tunagrahita. Pada suatu studi awal tentang mengenai keberadaan SLB disertai dengan siswanya di Kota Bandung yang dilaksanakan pada tahun 2014, diperoleh data bahwa data jumlah SLB di Kota Bandung berjumlah 46 SLB dengan jumlah siswa sebanyak 1500 siswa dengan berbagai keadaan, seperti: tunanetra; tunarungu; tunagrahita; tunadaksa; tunalaras; dan penyandang autis. Di antara populasi siswa tersebut, sebanyak $60 \%$ adalah anak tunagrahita ringan. Hasil penelitian awal menunjukkan bahwa keterampilan hidup personal yang diwujudkan dengan bentuk perilaku hidup bersih dan sehat pada anak tunagrahita kategori ringan masih rendah. Hal ini karena mereka belum memiliki kesadaran dan keterampilan dalam hal merawat diri, seperti menggunting kuku, menyisir rambut, mandi, makan dan minum dengan baik dan benar (Gunawan, 2017).

Pada penelitian yang dilakukan oleh Sari dan Santy (2017) didapat data dari suatu Sekolah Luar Biasa (SLB) Tunas Mulya di Surabaya pada tahun 2015 diketahui bahwa terdapat 27 siswa tunagrahita yang berada pada usia Sekolah Dasar, selain itu wawancara juga dilakukan kepada 6 wali murid. Diketahui bahwa 2 orang tua mengatakan anak mereka sudah dapat melakukan kegiatan bina diri yang terkait dengan kebersihan diri seperti mandi sendiri dan menggosok gigi sendiri. Sedangkan 4 orang tua lainnya mengatakan bahwa anak mereka masih memerlukan bantuan seperti mandi apabila dibiarkan maka anak hanya akan bermain air dan tidak melakukan kegiatan mandi, memakai sabun hanya sekedar dipakai tanpa membuat tubuhnya bersih, dalam hal menyikat gigi terkadang orang tua perlu mengulanginya kembali karena anak tidak melakukannya dengan baik sehingga kurang bersih, dan tidak semua anak dapat mengenakan baju berkancing (Sari \& Santy, 2017).

Mangunsong (2009) mengatakan bahwa dari segi pendidikan, individu dengan mild intellectual disability termasuk yang mampu didik, yaitu banyak diantara mereka yang mampu untuk mempelajari keterampilan hidup sehari-hari, serta vokasional. Individu dengan mild intellectual disability 
seringkali teridentifikasi ketika menghadapi tugas akademik yang semakin sulit (Heward, 2013). Kondisi tersebut disebabkan karena keterbatasan taraf kecerdasan mereka. Selain itu, banyak individu dengan mild intellectual disability kesulitan berkonsentrasi dalam jangka waktu yang lama (Mangunsong, 2009). Meski demikian, mereka dapat hidup sukses dalam komunitas, baik secara mandiri maupun dengan pengawasan, dan apabila mendapatkan dukungan yang sesuai (Mash \& Wolfe, 2005).

Pada penelitian ini, peneliti tertarik untuk meningkatkan kemampuan bina diri, yaitu mandi secara mandiri yang diterapkan kepada individu dengan mild intellectual disability. Hal ini dikarenakan mandi merupakan keterampilan yang harus dapat dilakukan secara mandiri, karena mandi berkaitan dengan menjaga kebersihan diri sendiri dan kesehatan kulit. Hal ini dikarenakan kebersihan badan atau kulit pada individu tersebut masih kotor karena mandi yang belum sesuai dengan tahapan dan target kebersihan badan (Gunawan, 2017). Lewis dan Iselin (dalam Rahmawati, Nani, Pratiwi, dan Purnamasari, 2014) mengatakan bahwa anak yang dapat melakukan perawatan diri dengan mandiri maka akan dapat berinteraksi dengan lingkungan lebih baik lagi dan dapat mengembangkan jejaring sosial lebih luas.

Dengan perlu adanya pemberian intervensi untuk meningkatkan kemampuan mandi secara mandiri pada individu dengan mild intellectual disability, maka ada banyak program dan teknik yang dapat digunakan untuk membantu dan mengembangkan fungsi adaptif pada individu dengan intellectual disability (Swapna \& Sudhir, 2016). Individu dengan mild intellectual disability dapat diberikan dukungan melalui treatment yang sesuai, yaitu dengan pendekatan behavioristik (behavioral approach), yaitu sebuah pendekatan mengenai perilaku yang menyatakan bahwa sebuah perilaku muncul akibat pengaruh dari lingkungan dan didapat melalui sebuah teknik belajar yaitu asosiasi (Kazdin, 2001). Pendekatan behavioristik yang digunakan ini adalah behavior modification, yaitu salah satu kajian psikologi yang berfokus pada analisa dan modifikasi perilaku, Analisa artinya mengidentifikasi hubungan fungsional kejadian di lingkungan dan perilaku tertentu untuk memahami alasan atau penyebab perilaku individu. Modifikasi berarti pengembangan dan penerapan prosedur untuk membantu individu mengubah perilakunya. Prosedur behavior modification dibentuk oleh professional dan digunakan untuk perubahan perilaku sosial secara signifikan, dengan tujuan untuk meningkatkan aspek kehidupan seseorang (Miltenberger, 2012). Behavior modification memberikan perhatian khusus pada perilaku dan performa, atau hal yang dilakukan dalam kehidupan sehari-hari. Pendekatan ini berfokus pada perkembangan adaptif, perilaku prososial, dan mengurangi perilaku maladaptif dalam kehidupan sehari-hari (Kazdin, 2013). Selain itu, behavior modification digunakan karena merupakan intervensi yang paling tepat karena berfokus pada perilaku sesuai target yang ingin diubah (New York State Education Departement, 2011).

Pada program behavior modification ini digunakan teknik chaining. Metode chaining dapat dilakukan secara forward atau backward, tergantung dari kemampuan yang telah dikuasai anak (Kazdin, 2013). Teknik yang digunakan adalah forward chaining, karena anak sudah mulai dapat melakukan langkahlangkah awal kegiatan mandi.

Social reinforcers seperti pujian secara verbal, perhatian, kontak fisik (termasuk sentuhan kasih sayang atau rasa bangga, tepukan, dan pegangan tangan) dan ekspresi wajah (termasuk senyuman, kontak mata, anggukan, dan kedipan mata) merupakan reinforcement yang terkondisikan. Beberapa 
penelitian telah menunjukkan bahwa perhatian atau pujian dari orangtua, guru, atau teman sebaya digunakan untuk mengontrol perilaku (Kazdin, 2013).

Teknik yang digunakan pada program ini dalam memodifikasi perilaku yang diinginkan adalah teknik chaining dan teknik reinforcement. Teknik chaining digunakan dalam memodifikasi perilaku mandi dilakukan dengan memberikan prompting saat subyek melakukan langkah-langkah kegiatan mandi.

Program ini menggunakan social reinforcers berupa senyuman dan tepukan tangan (toss) sebagai tanda bahwa subyek sudah berhasil menyelesaikan setahap demi setahap dengan baik. Dalam melakukan perilaku yang kompleks seperti mandi, terkadang perlu untuk memecah langkah-langkah yang harus dikerjakan. Salah satu cara dalam mengajarkan suatu perilaku yang kompleks adalah dengan menggunakan task analysis. Task analysis biasa digunakan untuk mengajarkan individu yang memiliki keterlambatan perkembangan dalam melakukan suatu perilaku yang kompleks (Bennet, 2009).

Pemilihan teknik chaining, yang disertai dengan pemberian prompting pada penelitian ini didasarkan pada penelitian yang dilakukan oleh Sabielny dan Cannella-Malone (2014), dimana hasil penelitian menunjukkan bahwa penggunaan prompting terbukti efektif dalam meningkatkan keterampilan bina diri pada individu dengan mild intellectual disability. Selain itu, peneliti memilih untuk memberi intervensi pada kemampuan bina diri, seperti mandi secara mandiri pada individu dengan mild intellectual disability karena kemampuan bina diri merupakan hal yang perlu untuk ditingkatkan. Hal ini karena kemampuan bina diri merupakan tahapan pertama dari proses pencapaian kemandirian individu dan keterampilan bina diri akan terus digunakan sepanjang usia kehidupan individu dengan intellectual disability (Ardic \& Cavkaytar, 2014).

\section{Rumusan Masalah}

Apakah teknik forward chaining yang disertai dengan pemberian prompt dan social reinforcement dapat meningkatkan kemampuan mandi secara mandiri pada remaja dengan mild intellectual disability?

\section{METODE PENELITIAN Partisipan}

Seorang remaja perempuan yang berinisial A dan berusia 14 tahun 1 bulan dengan gangguan intellectual disability tingkatan ringan. Pihak panti asuhan, yakni pengasuh mengeluhkan kemampuan remaja tersebut dalam melakukan kegiatan sehari-hari yakni bina diri untuk menjaga kebersihan diri, dimana salah satunya adalah melakukan kegiatan mandi secara mandiri. Remaja tersebut belum dapat melakukan kegiatan mandi secara mandiri, dimana dalam melakukan kegiatan mandi perlu mendapatkan bantuan berupa pengawasan dan pengarahan secara fisik maupun verbal. Pengasuh mengeluhkan adanya kesulitan dalam melakukan kegiatan mandi secara mandiri karena remaja tersebut harus selalu diberikan pengawasan dan pengarahan secara fisik maupun verbal, namun tetap tidak bisa. Selain itu berdasarkan hasil observasi, kebersihan diri pada remaja tersebut tampak tidak terjaga dengan baik. Terlihat dengan aroma tubuhnya yang tidak sedap dan banyak terdapat kotoran pada anggota tubuhnya yang luput dari perhatiannya untuk dibersihkan.

\section{Setting dan Perlengkapan}


Pemberian intervensi dilakukan di panti asuhan, tepatnya di dalam kamar mandi rumah perempuan. Pada kamar mandi sudah tersedia kapstok, untuk memudahkan subyek meletakkan pakaian bersih yang akan digunakan setelah mandi, handuk, dan pakaian kotor yang telah dipakai subyek sebelum mandi, selain itu di kamar mandi juga sudah tersedia wadah air dan gayung. Perlengkapan yang dibutuhkan dalam melakukan kegiatan intervensi ini antara lain shampoo, sabun, wadah air dan gayung, keran air, handuk, dan pakaian bersih. Intervensi ini dilakukan pada saat kegiatan mandi di pagi dan sore hari.

\section{Prosedur}

\section{Task analysis}

Dalam melakukan perilaku yang kompleks seperti mandi, terkadang perlu untuk memecah langkahlangkah yang harus dikerjakan. Salah satu cara dalam mengajarkan suatu perilaku yang kompleks adalah dengan menggunakan task analysis. Task analysis biasa digunakan untuk mengajarkan individu yang memiliki keterlambatan perkembangan dalam melakukan suatu perilaku yang kompleks (Bennet, 2009). Task analysis yang digunakan dalam kegiatan mandi dengan mandiri adalah: (1) mempersiapkan peralatan mandi (membawa handuk dan baju bersih); (2) masuk ke kamar mandi, kemudian menutup pintu kamar mandi; (3) meletakkan handuk di gantungan atau kapstok; (4) membuka semua pakaian; (5) letakkan pakaian di gantungan atau kapstok; (6) menyalakan keran air dan pegang gayung; (7) mengambil air di ember dengan gayung; (8) siram seluruh tubuh dengan gayung yang terisi air sebanyak 4 sampai 5 kali hingga tubuh basah secara keseluruhan; (9) ambil dan tuangkan shampoo secukupnya pada telapak tangan; (10) meletakkan telapak tangan di kepala/rambut; (11) memijat seluruh daerah rambut hingga berbusa; (12) membilas rambut dengan air hingga bersih dari busa shampoo; (13) ambil dan basahi sabun yang sudah disediakan; (14) gosok sabun ke wajah, leher, dan belakang telinga; (15) gosok sabun ke lengan dan ketiak, badan dan punggung, kedua kaki dan jemarinya.; (16) bilas seluruh tubuh hingga bersih dan tidak ada busa sabun yang tertinggal; (17) keringkan tubuh dengan handuk dimulai dari rambut, wajah, leher, telinga, lengan dan ketiak, badan, punggung, dan kaki, hingga kering secara sempurna; (18) berpakaian; (19) keluar dari kamar mandi.

\section{Experimental design}

Penelitian ini termasuk ke dalam jenis penelitian single-subject experimental designs. Horner et. al. (dalam Byiers et al., 2012) mengatakan bahwa penelitian dengan jenis single-subject experimental designs adalah suatu desain penelitian eksperimental yang digunakan untuk membantu mengidentifikasi efektivitas dari suatu intervensi. Jumlah partisipan pada penelitian single-subject experimental designs hanya terdiri dari satu atau sedikit yang dapat dihitung sebagai satu buah unit (Ary et al., 2010).

\section{Baseline}

Pada pengukuran baseline, subyek diminta untuk melakukan kegiatan mandi secara mandiri. Peralatan mandi sudah disiapkan oleh pihak panti asuhan di masing-masing kamar penghuni panti, dimana subyek dapat membawanya ke kamar mandi. Tugas peneliti yaitu mengecek apabila ada peralatan mandi yang kurang dan mengingatkan kepada subyek peralatan apa saja yang diperlukan. Di tahap baseline ini, peneliti tidak memberikan penguatan apapun ketika subyek melakukan kegiatan mandi secara mandiri. Sesi baseline berakhir ketika subyek secara konsisten menampilkan perilaku yang sama selama dilakukannya sesi baseline. Pengukuran baseline dilakukan selama tiga buah sesi, yaitu selama tiga hari pada tanggal 23 Agustus 2017 sampai dengan 25 Agustus 2017. Waktu pelaksanaan 
pengukuran baseline dilakukan pada sore hari, yaitu pada saat kegiatan mandi sore sekitar pukul 16.30 $-17.00 \mathrm{WIB}$.

\section{Intervensi}

Intervensi dilaksanakan mulai tanggal 28 Agustus 2017 sampai dengan tanggal 1 September 2017, dimana setiap hari akan dilakukan dua buah sesi intervensi, yaitu pada saat kegiatan mandi pagi (sekitar pukul 05.30 WIB) dan kegiatan mandi sore (sekitar pukul 16.30 WIB). Sesi intervensi selalu dimulai dengan peneliti memberikan subyek prompting yang dirancang untuk pembentukan perilaku mandi secara mandiri dengan benar dan yang diinginkan secara bertahap. Subyek akan diberikan arahan untuk melakukan kegiatan mandi menggunakan prompting. Subyek akan diberikan instruksi untuk mempersiapkan peralatan mandi (membawa handuk dan baju bersih), masuk ke kamar mandi, kemudian menutup pintu kamar mandi, meletakkan handuk di gantungan atau kapstok, membuka semua pakaian, meletakkan pakaian di gantungan atau kapstok, menyalakan keran air dan memegang gayung, mengambil air di ember dengan gayung, membasuh seluruh tubuh dengan gayung yang terisi air sebanyak 4 sampai 5 kali hingga tubuh basah secara keseluruhan, mengambil dan menuangkan shampoo secukupnya pada telapak tangan, meletakkan telapak tangan di kepala/rambut, memijat seluruh daerah rambut hingga berbusa, membilas rambut dengan air hingga bersih dari busa shampoo, mengambil dan membasahi sabun yang sudah disediakan, menggosok sabun ke wajah, leher, dan belakang telinga, menggosok sabun ke lengan dan ketiak, badan dan punggung, kedua kaki dan jemarinya, membilas seluruh tubuh hingga bersih dan tidak ada busa sabun yang tertinggal, mengeringkan tubuh dengan handuk dimulai dari rambut, wajah, leher, telinga, lengan dan ketiak, badan, punggung, dan kaki, hingga kering secara sempurna, berpakaian, dan keluar dari kamar mandi.

Pada intervensi ini dijelaskan kepada subyek bahwa setiap subyek berhasil menyelesaikan setiap langkah dengan benar, maka ia akan mendapatkan senyuman, dan ketika subyek dapat menyelesaikan kegiatan keseluruhan, maka subyek diajak untuk melakukan tepukan tangan (toss) dengan peneliti. Hal ini karena social reinforcers seperti pujian secara verbal, perhatian, kontak fisik (termasuk sentuhan kasih sayang atau rasa bangga, tepukan, dan pegangan tangan) dan ekspresi wajah (termasuk senyuman, kontak mata, anggukan, dan kedipan mata) merupakan reinforcement yang terkondisikan. Beberapa penelitian telah menunjukkan bahwa perhatian atau pujian dari orangtua, guru, atau teman sebaya digunakan untuk mengontrol perilaku (Kazdin, 2013).

\section{Evaluasi}

Teknik evaluasi yang dilakukan adalah teknik A-B design, yaitu dengan mengukur efektivitas dari intervensi dengan mengukur kondisi baseline atau kondisi tanpa intervensi (fase A) dan kondisi saat intervensi dilakukan (fase B). Teknik ini diawali dengan observasi perilaku untuk menentukan baseline (fase A). Setelah menemukan kestabilan dalam perilaku target, maka intervensi diberikan (fase B). Kemudian, kedua kondisi ini dibandingkan untuk melihat efektivitas pemberian modifikasi perilaku.

Secara keseluruhan, dari fase A dan fase B menunjukan adanya perbedaan yang cukup signifikan, sehingga dapat dikatakan bahwa intervensi yang diberikan kepada subyek cukup efektif dan berhasil karena berdasarkan baseline, terdapat 10 perilaku yang belum muncul atau dilakukan oleh subyek. Akan tetapi, ketika intervensi sudah diberikan maka subyek dapat memunculkan 8 perilaku yang sebelumnya belum muncul. 2 perilaku yang belum muncul atau dilakukan subyek karena sesi intervensi dengan disertai prompting berlangsung kurang lama mengingat bahwa subyek merupakan 
individu dengan Intellectual Disability tingkatan ringan dan tahapan yang diberikan seharusnya mencakup 12 - 15 tahapan.

\section{Maintenance}

Maintenance yang dilakukan berupa adult facilitator di mana wali kelas atau pengasuh akan melanjutkan untuk mengawasi dan mempertahankan pemberian reinforcement (continuous) setiap kali perilaku yang diinginkan muncul.

\section{HASIL DAN PEMBAHASAN}

Berdasarkan intervensi yang telah dilakukan kepada subjek maka diperoleh hasil bahwa pada tahap baseline, subyek tampak belum menampilkan perilaku mandi sesuai dengan langkah-langkah yang tepat atau dengan kata lain selama sesi baseline subyek menampilkan perilaku dengan konsisten. Saat observasi dilakukan, subyek tidak meletakkan handuk di gantungan atau kapstok, meletakkan pakaian di gantungan atau kapstok, membasuh atau menyiram seluruh tubuh dengan gayung yang terisi air sebanyak 4 sampai 5 kali hingga tubuh basah secara keseluruhan, memijat seluruh daerah rambut dengan berbusa, membilas rambut dengan air hingga bersih dari busa shampoo, menggosok sabun ke wajah, leher, dan belakang telinga, menggosok sabun ke lengan dan ketiak, badan dan punggung, kedua kaki dan jemarinya, membilas seluruh tubuh hingga bersih dan tidak ada busa sabun yang tertinggal, mengeringkan tubuh dengan handuk dimulai dari rambut, wajah, telinga, lengan dan ketiak, badan, punggung, dan kaki, hingga kering secara sempurna, dan berpakaian.

Setelah diberikan intervensi, pada sesi keempat subyek sudah menunjukkan rangkaian mandi secara mandiri dengan benar, tetapi masih diberikan prompt berupa arahan dari pemeriksa. Pada hari ketujuh hingga hari kesembilan, prompt dihilangkan, subyek sudah mampu untuk melakukan beberapa rangkaian perilaku mandi secara mandiri dengan benar meskipun belum sempurna.

Secara keseluruhan, dari fase A dan fase B menunjukan adanya perbedaan yang cukup signifikan, sehingga dapat dikatakan bahwa intervensi yang diberikan kepada subyek cukup efektif dan berhasil karena berdasarkan baseline, terdapat 10 perilaku yang belum muncul atau dilakukan oleh subyek. Akan tetapi, ketika intervensi sudah diberikan maka subyek dapat memunculkan 8 perilaku yang sebelumnya belum muncul. 2 perilaku yang belum muncul atau dilakukan subyek karena sesi intervensi dengan disertai prompting berlangsung kurang lama mengingat bahwa subyek merupakan individu dengan Intellectual Disability tingkatan ringan dan tahapan yang diberikan seharusnya mencakup 12 - 15 tahapan. Hasil data pengukuran baseline dan sesi intervensi baik yang menggunakan prompting dan tanpa menggunakan prompting mandi secara mandiri dapat dilihat pada table 1 . 
Tabel 1.

Hasil data pengukuran baseline dan sesi intervensi (disertai prompting dan tanpa prompting)

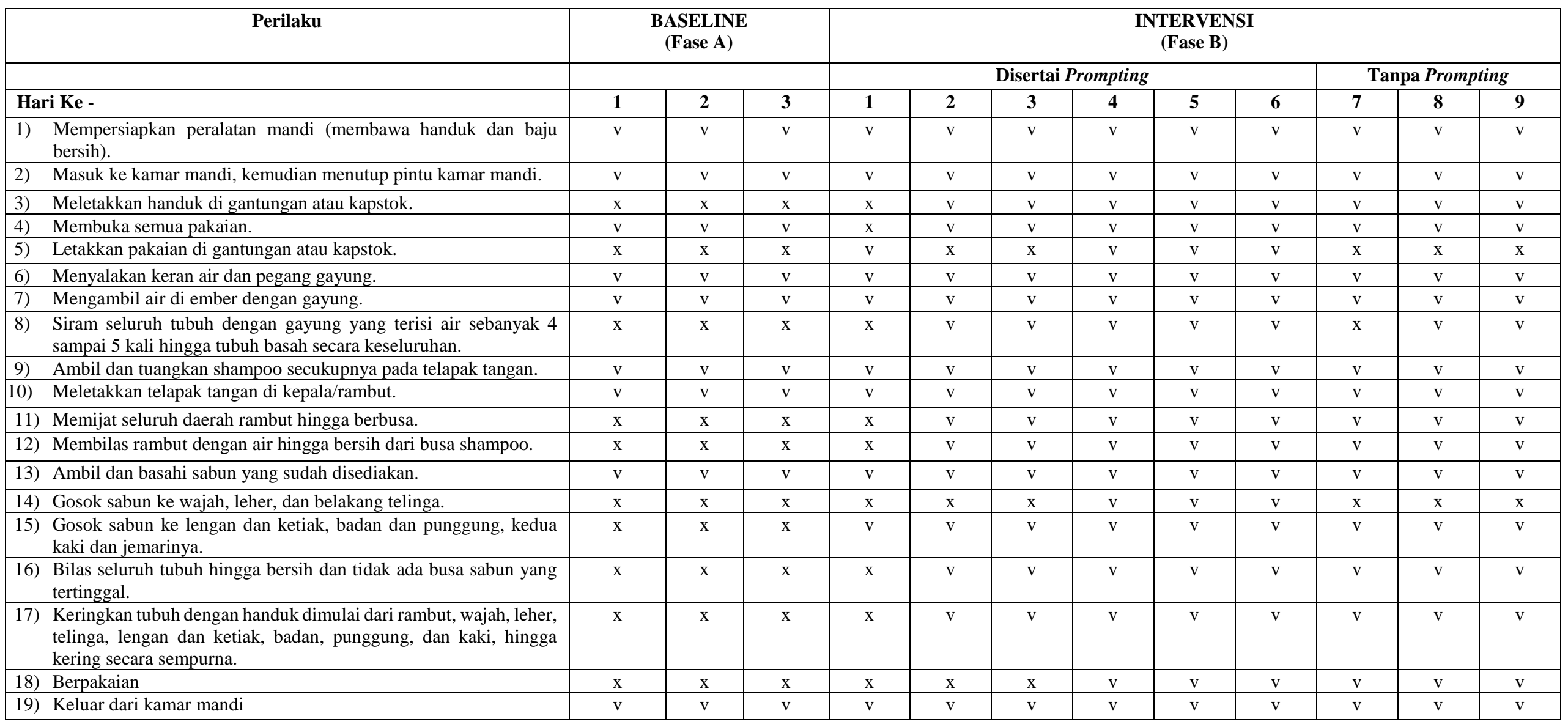


Penerapan Forward Chaining Dalam Meningkatkan

Kemampuan Mandi Secara Mandiri Pada Remaja

Dengan Mild Intellectual Disability

Adanya peningkatan kemampuan remaja tersebut dalam mandi secara mandiri dipengaruhi oleh beberapa faktor, yaitu pertama, pengajaran mandi secara mandiri kepada subyek selalu diawali dengan pemberian arahan atau instruksi cara mandi yang benar sebelum subyek memulai kegiatan mandiri secara mandiri. Hal tersebut cukup membantu proses pengajaran karena anak diingatkan kembali mengenai langkah-langkah mandi secara mandiri dengan tepat. Hal yang dilakukan peneliti sesuai dengan karakteristik kemampuan belajar yang dibutuhkan oleh individu yang memiliki hambatan dalam inteligensi, yaitu mereka memiliki kesulitan untuk memahami hal yang bersifat abstrak. Oleh karena itu pengajaran yang diberikan akan lebih mudah dipahami apabila diberikan secara konkret atau dengan disertai contoh (Shaw, 2010). Kedua, pengajaran yang konsisten dan berulang dapat membantu individu dengan mild intellectual disability untuk memahami dan mengingat perilaku yang diajarkan dan diharapkan. Hal ini sesuai dengan karakteristik dari intellectual disability, yaitu individu memiliki kesulitan untuk memproses informasi atau mengingat suatu hal, sehingga individu membutuhkan lebih banyak pengulangan dalam memproses informasi atau mengingat suatu hal (Westwood, 2009). Selain itu, pemberian social reward, seperti senyuman dan toss ketika remaja tersebut dapat melakukan tahapan dengan benar juga merupakan faktor keberhasilan dalam penelitian ini.

\section{KESIMPULAN DAN SARAN}

Berdasarkan intervensi yang sudah dilakukan kepada remaja tersebut, diperoleh hasil bahwa telah terbentuk perilaku mandi sebagai bagian dari kemampuan bina diri pada remaja dengan intellectual disability tingkatan ringan. Hal ini ditunjukkan dengan adanya 7 tahap telah terbentuk dari 19 perilaku yang sebelumnya tidak pernah muncul, yaitu pada tahap awal subyek bisa menunjukkan 9 tahap menjadi 7 tahap baru, sehingga hanya 2 tahap yang belum terbentuk secara mandiri. Peneliti menyimpulkan bahwa program modifikasi perilaku dengan menggunakan teknik forward chaining disertai dengan pemberian prompt dan social reinforcement menampilkan efektivitas jangka panjang, di mana perilaku mandi secara mandiri dengan langkah-langkah yang tepat dapat dipertahankan oleh subyek apabila terus dilakukan penguatan dengan berulang dan jangka waktu yang panjang atau sesi lebih banyak. Menurut pengasuh, saat ini subyek sudah lebih mampu untuk melakukan perilaku mandi secara mandiri dengan benar.

Berdasarkan penelitian yang sudah dilakukan, peneliti menyadari bahwa penelitian ini masih memiliki keterbatasan yang perlu untuk ditingkatkan. Untuk itu peneliti dapat memberikan saran kepada penelitian selanjutnya mengingat intervensi ini dilakukan kepada individu usia remaja dengan intellectual disability kategori ringan, yaitu sebaiknya ada penambahan sesi waktu pelaksanaan intervensi, baik yang menggunakan prompting ataupun tanpa menggunakan prompting. Hal ini dimaksudkan agar perilaku dapat terbentuk sesuai dengan tahap-tahap tugas yang harus dilakukan dan perilaku yang sudah terbentuk dapat bertahan untuk dilakukan secara mandiri di kemudian hari. Selain itu, apabila penelitian ditujukan kepada individu dengan intellectual disability tingkatan ringan, sebaiknya tahapan mandi yang diberikan fokus dalam hal membersihkan tubuh saja atau membersihkan rambut. Hal tersebut dimaksudkan agar kualitas dalam menjaga kebersihan tubuh, yaitu kegiatan mandi dapat dikuasai dengan baik.

\section{Ucapan Terima Kasih}

Peneliti mengucapkan terima kasih kepada panti asuhan yang sudah memberikan izin dan kesempatan untuk melakukan penelitian, khususnya kepada kepala panti asuhan dan para pengasuh 
untuk meluangkan waktu dalam kegiatan pengumpulan data, memberikan izin tempat pelaksanaan intervensi, dan mengizinkan subyek untuk mengikuti kegiatan intervensi.

\section{REFERENSI}

American Association on Mental Deficiency. (1983).. Classification In Mental Retardation. American Association of Mental Deficiency: Washington.

American Psychiatric Association. (2013). Diagnostic and statistical manual of mental disorder (5th ed.). American Psychological Association: Washington, DC.

Ardic, A., \& Cavkaytar, A. (2014). Effectiveness of the Modified Intensive Toilet Training Method on Teaching Toilet Skills to Children with Autism. Education and Training in Autism and Developmental Disabilities, 49 (2), 263 - 276.

Ary, D., Jacobs, L. C., Sorensen, C., \& Razavich, A. (2010). Introduction to research in education. California: Wadsworth Cengage Learning.

Bennett, E. P. (2009). Comparison of Backward and Forward Chaining in the Acquisition of Play and Vocational Skills. Boston: Northeastern University.

Byiers, B. J., Reichle, J., \& Symons, F. J. (2012). Single-subject experimental design for evidencebased practice. American Journal of Speech-Language Pathology, 21, 397- 414.

Ersoy, G., Tekin-Iftar, E., \& Kircaali-Iftar, G. (2009). Effects of Antecedent Prompt and Test Procedure on Teaching Simulated Menstrual Care Skills to Females with Developmental Disabilities. Education and Training in Developmental Disabilities, 44 (1), 54-66.

Gunawan, A. A., Nurihasan, A. J., \& Sunanto, J. (2017). Bimbingan Keterampilan Hidup Personal Bagi Anak Tuna Grahita Ringan di SLB Kota Bandung. Jurnal Ilmiah Mitra Swara Ganesha, $4(1), 58-95$.

Heward, W. L. (2013). Exceptional Childrens an Introduction to Special Education (10thed.) Saddle River, NJ: Pearson Education.

Kazdin, A. E. (2001). Behavior modification in applied settings (6th ed.). Long Grove, Illinois: Waveland Press, Inc.

Kazdin, A. E. (2013), Behavior Modification in Applied Settings (7th ed.). Illionis: Waveland Press, Inc.

Mangunsong, F. (2009). Psikologi dan Pendidikan Anak Berkebutuhan Khusus (Jilid 1). Depok: Lembaga Pengembangan Sarana Pengukuran dan Pendidikan Psikologi (LPSP3).

Mash, E. J., \& Wolfe, D. A. (2005). Abnormal Child Psychology (3rded). Belmont, CA: Thomson Wadsworth.

Mash, E. J., \& Wolfe, D. A. (2013). Abnormal Child Psychopatology (5thed.). USA: Wadsworth.

Nelson, R., \& Israel, A. C. (2015). Abnormal child and adolescent psychology with DSM-V updates (8th ed.). New York: Pearson.

New York State Education Departemen. (2011). Special Education: Behavioral Intervention Plans. University of the State of New York.

Rahmawati, D., Nani, D., Pratiwi, H. M., \& Purnamasari, M. D. (2014). Self-Care Management Training Meningkatkan Pengetahuan Orangtua dan Kemampuan Perawatan Diri Anak Retardasi Mental. 277-285.

Sabielny, L. M., \& Cannella-Malone, H.I., (2014). Comparison of Prompting Strategies on the Acquisition of Daily Living Skills. Education and Training in Autism and Developmental Disabilities, 49 (1), 145 - 152. 
Sari, O. A., \& Santy, W. H. (2017). Hubungan Dukungan Keluarga dengan Tingkat Kemandirian Personal Hygiene Anak Tunagrahita di SLB Tunas Mulya Kelurahan Semewi Kecamatan Benowo. Jurnal Ilmiah Kesehatan, 10 (2), 164 - 171.

Sattler, J. M. (2002). Assessment of Children (Behavioral and Clinical Applications (4thed.). San Diego: Jerome M. Sattler, Publisher, Inc.

Shaw, S. R. (2010, February). Rescuing Students From the Slow Learner Trap. Principal Leadership, 10 (6), 12-16.

Swapna., \& Sudhir, M.A. (2016). Behavior Modification for Intellectually Disabled Students. IOSR Journal of Humanities and Social Science, 21 (2), 35 - 38.

Westwood, P. (2009). What teachers need to know about students with disabilities. Victoria: Acer Press. 